\title{
Phenotypic and genotypic characterization of locally isolated Salmonella strains used in preparation of Salmonella antigens in Egypt
}

\author{
Hazem Mohammed Ibrahim¹ ${ }^{1}$ Dalia Ahmed Mohammed Abd El-Moaty², Hanan Ali Ahmed ${ }^{3}$ and Mona Ibrahim El-Enbaawy
}

1. Department of Bacterial Sera and Antigens Research, Veterinary Serum and Vaccine Research Institute, Abbasia, Cairo, Egypt; 2. Genetic Engineering Research Department, Veterinary Serum and Vaccine Research Institute, Abbasia, Cairo, Egypt; 3. Central Laboratory for Evaluation of Veterinary Biologics, Cairo, Egypt; 4. Department of Microbiology, Faculty of Veterinary Medicine, Cairo University, Cairo, Egypt.

Corresponding author: Hazem Mohammed Ibrahim, e-mail: dr.hazemibrahim@gmail.com, DAMA: dody.ahmed@gmail.com, HAA: vetehana@yahoo.com, MIE: dr mona 1@hotmail.com Received: 16-08-2016, Accepted: 09-11-2016, Published online: 17-12-2016

doi: 10.14202/vetworld.2016.1435-1439 How to cite this article: Ibrahim HM, Abd El-Moaty DAM, Ahmed HA, El-Enbaawy MI (2016) Phenotypic and genotypic characterization of locally isolated Salmonella strains used in preparation of Salmonella antigens in Egypt, Veterinary World, 9(12): 1435-1439.

\begin{abstract}
Aim: This work was conducted to study the phenotypic and genotypic characterization of locally isolated Salmonella strains (Salmonella Pullorum, Salmonella Enteritidis, and Salmonella Typhimurium) from poultry used in the preparation of Salmonella antigens in Egypt.
\end{abstract}

Materials and Methods: The phenotypic characterization of Salmonella strains was done using standard microbiological, biochemical, and serological techniques. Molecular identification was done using different sets of primers on different genes using different polymerase chain reaction (PCR) techniques.

Results: The phenotypic characterization of Salmonella strains was confirmed. Molecular identification revealed detection of $284 \mathrm{bp}$ fragment of InvA gene in all studied Salmonella strains. Furthermore, multiplex PCR was used for more confirmation of being Salmonella spp., generally at 429 bp as well as genotyping of Salmonella Typhimurium and Salmonella Enteritidis at 559 and $312 \mathrm{bp}$, respectively, in one reaction.

Conclusion: The locally isolated field Salmonella strains were confirmed phenotypically and genotypically to be Salmonella Enteritidis, and Salmonella Typhimurium and could be used for the preparation of Salmonella antigens.

Keywords: characterization, duplex polymerase chain reaction, multiplex polymerase chain reaction, Salmonella spp.

\section{Introduction}

Salmonella organisms are responsible for a variety of acute and chronic diseases in poultry, animals, and humans [1]. Salmonella bacteria are facultative intracellular pathogens causing localized or systemic infections, in addition to a chronic asymptomatic carrier state. Many different serotypes of Salmonella have been isolated from poultry, most of them have a public health significance, but some include Salmonella Typhimurium, Salmonella Enteritidis, Salmonella Pullorum, and Salmonella Gallinarum can cause considerable losses in birds of less than a few weeks of age [2]. Salmonella enterica serovars Typhimurium and Salmonella enterica serovars Enteritidis are the most frequently isolated serovar from foodborne outbreaks throughout the world [3]. Salmonella Pullorum is a typical bacterial disease that has threaten the modern poultry industry over the past years. Chicken becomes the carrier in the spread of Salmonella Pullorum and may cause economic losses

Copyright: Ibrahim, et al. Open Access. This article is distributed under the terms of the Creative Commons Attribution 4.0 International License (http://creativecommons.org/licenses/ by/4.0/), which permits unrestricted use, distribution, and reproduction in any medium, provided you give appropriate credit to the original author(s) and the source, provide a link to the Creative Commons license, and indicate if changes were made. The Creative Commons Public Domain Dedication waiver (http:// creativecommons.org/publicdomain/zero/1.0/) applies to the data made available in this article, unless otherwise stated. worldwide through mortality, morbidity, and reductions in egg production [4]. Establishing conventional methods was applied to detect and identify Salmonella include selective enrichment and plating followed by biochemical tests and serological identification [5]. In general, these techniques are time-consuming since they give only presumptive results after 3-4 days and definitive results after 5-6 days [6]. However, because of controversy in interpreting results, low sensitivity and specificity of these methods, rapid detection methods, such as DNA or RNA probing, immuno-detection methods and nucleic acid hybridization have been developed, but they do not have enough sensitivity and specificity [7].

In vitro amplification of DNA by the polymerase chain reaction (PCR) method is a powerful tool in microbiological diagnostics [8]. Several genes have been used to detect Salmonella in natural environmental samples as well as food and fecal samples. Virulence chromosomal genes - including invA, invE and himA, phoP - are target genes for PCR amplification of Salmonella species [9]. The invA gene of Salmonella contains sequences unique to this genus and has been proved as a suitable PCR target with potential diagnostic applications [10]. Multiplex PCR simultaneously detecting several pathogens in a single-tube reaction and has the potential of saving time and effort, lowering testing-related laboratory cost [11]. Typing of 
Salmonella Enteritidis and Typhimurium using multiplex PCR reaction is depending on sefA gene which encodes for SEF14 fimbrial antigen characteristic for Salmonella Enteritidis while fliC gene variable region encoding for flagellin $\mathrm{H} 1$ was characteristic for Salmonella Typhimurium [12].

The objective of this work was to characterize the locally isolated Salmonella strains used in the preparation of Salmonella antigens in Egypt by both phenotypic and genotypic methods.

\section{Materials and Methods}

\section{Ethical approval}

The approval from the Institutional Animal Ethics Committee to carry out this study was not required as no invasive technique was used.

\section{Bacterial strains}

Three local field Salmonella strains (Salmonella Pullorum, Salmonella Enteritidis, and Salmonella Typhimurium) isolated from chickens, kindly obtained from Bacterial Sera and Antigens Research Department, Veterinary Serum and Vaccine Research Institute, Abbasia, Egypt were used to study their phenotypic and genotypic characterization. All isolates were confirmed as Salmonella different types using both morphological and biochemical identification [13]. Serological typing was performed using reference Salmonella antisera [14].

\section{Total DNA extraction of Salmonella isolates}

That was performed by boiling the overnight incubated culture broth for $10 \mathrm{~min}$ in dry bath and centrifuged at $5000 \times \mathrm{g}$ for $10 \mathrm{~min}$. The supernatant was used for amplification by PCR using Salmonellaspecific primers. The extract was divided into aliquots and kept at $-20^{\circ} \mathrm{C}$ until use as PCR template [15].

\section{Primers set}

Primers used were supplied by Metabion (Germany) and summarized in Table-1. For diagnosis of Salmonella spp. generally, a primer set was used for amplification of $284 \mathrm{bp}$ of InvA gene [10]. Another primer sets were used for general identification of Salmonella spp. as well as typing of Salmonella Typhimurium and Salmonella Enteritidis in a multiplex PCR reaction [12]. Typing of Salmonella Pullorum was done using a duplex PCR, to differentiate between Salmonella Gallinarum and Salmonella Pullorum depending on the presence of speC gene in both strains but glgC gene is unique for Salmonella Gallinarum only [16].

\section{PCR amplification}

Amplification was performed as following: $12.5 \mu \mathrm{l}$ of $\times 2$ Dream Taq Green PCR Master Mix (Fermentas), 100 pmol of upstream primer, 100 pmol of downstream primer, $4 \mu 1$ of template DNA and nuclease-free water up to $25 \mu \mathrm{l}$ using thermal cycler PerkinElmer Gene Amp PCR system 9700. Amplification conditions of $284 \mathrm{bp}$ of InvA gene where the thermal cycler were adjusted to 1 cycle at $95^{\circ} \mathrm{C}$ for $1 \mathrm{~min}$, then 35 cycles at $95^{\circ} \mathrm{C}$ for $1 \mathrm{~min}, 64^{\circ} \mathrm{C}$ for $30 \mathrm{~s}, 72^{\circ} \mathrm{C}$ for $30 \mathrm{~s}$ followed by 1 cycle at $94^{\circ} \mathrm{C}$ for 4 min [17]. For multiplex PCR, the amplification conditions were adjusted to 1 cycle at $94^{\circ} \mathrm{C}$ for $1 \mathrm{~min}$, 35 cycles at $94^{\circ} \mathrm{C}$ for $30 \mathrm{~s}, 56^{\circ} \mathrm{C}$ for $1 \min 30 \mathrm{~s}, 72^{\circ} \mathrm{C}$ for $30 \mathrm{~s}$ followed by 1 cycle at $72^{\circ} \mathrm{C}$ for $10 \mathrm{~min}$ [12]. Duplex PCR was performed [16,18], with a wide range of annealing temperatures, where PCR conditions were 1 cycle at $95^{\circ} \mathrm{C}$ for $5 \mathrm{~min}, 35$ cycle of $95^{\circ} \mathrm{C}$ for $30 \mathrm{~s}, 55-65^{\circ} \mathrm{C}$ for $30 \mathrm{~s}$, and $72^{\circ} \mathrm{C}$ for $30 \mathrm{~s}$ followed by a final extension step at $72^{\circ} \mathrm{C}$ for $10 \mathrm{~min}$. Sterile DNase and RNase free water were used as negative PCR control.

\section{Analysis of PCR products}

All amplified products were analyzed by electrophoresis using 1-1.5\% agarose gel (Applichem, Germany, GmbH) and visualized by ultraviolet transilluminator after gel staining with ethidium bromide stain (Fisher). The product size was measured using 100 bp DNA Ladder (Fermentas) that was used as a

Table-1: Primer sets for Salmonella strains PCR.

\begin{tabular}{|c|c|c|c|c|c|}
\hline $\begin{array}{l}\text { Primer } \\
\text { set }\end{array}$ & $\begin{array}{l}\text { Salmonella } \\
\text { strain }\end{array}$ & Target gene & $\begin{array}{l}\text { Primer sequence } \\
5^{\prime}---3^{\prime}\end{array}$ & Length & $\begin{array}{c}\text { Amplicon } \\
\text { fragment (bp) }\end{array}$ \\
\hline S139 & Salmonella spp. & invA gene & GTG AAA TTA TCG CCA CGT TCG GGC AA & 26 & 284 \\
\hline S141 & & & TCA TCG CAC CGT CAA AGG AAC C & 22 & \\
\hline ST11 & Salmonella spp. & $\begin{array}{l}\text { Randomly cloned } \\
\text { chromosomal fragment }\end{array}$ & AGCCAACCATTGCTAAATTGGCGCA & 25 & 429 \\
\hline ST15 & & & GGTAGAAATTCCCAGCGGGTACTG & 24 & \\
\hline Fli 15 & $\begin{array}{l}\text { Salmonella } \\
\text { Typhimurium }\end{array}$ & flic & CGG TGT TGC CCA GGT TGG TAA T & 22 & 559 \\
\hline Tym & & & ACT CTT GCT GGC GGT GCG ACT T & 22 & \\
\hline Sef167 & $\begin{array}{l}\text { Salmonella } \\
\text { Enteritidis }\end{array}$ & SefA gene & AGG TTC AGG CAG CGG TTA CT & 20 & 312 \\
\hline Sef478 & & & GGG ACA TTT AGC GTT TCT TG & 20 & \\
\hline SG-L & $\begin{array}{l}\text { Salmonella } \\
\text { Pullorum }\end{array}$ & $g \lg C$ & GAT CTG CTG CCA GCT CAA & 18 & 252 \\
\hline SG-R & & & GCG CCC TाT TCA AAA CAT A & 19 & \\
\hline SGP-L & & speC & CGG TGT ACT GCC CGC TAT & 18 & 174 \\
\hline SGP-R & & & CTG GGC ATT GAC GCA AA & 17 & \\
\hline
\end{tabular}

$\mathrm{PCR}=$ Polymerase chain reaction 
marker for PCR products. The gel was photographed by a gel documentation system (Alpha Innotech, Biometra), and the data were analyzed through computer software.

\section{DNA sequence and analysis}

PCR fragment of speC gene of Salmonella Pullorum was purified with agarose gel extraction kit Qiaquick (Qiagen, Germany). Sequence analysis of this fragment was performed using the same PCR primers (Macrogen Inc., Seoul, Korea).

\section{Results}

In this study, three locally fields isolated Salmonella strains used in preparation of Salmonella antigens in Egypt were tested and confirmed to be Salmonella species phenotypically by culturing and biochemical testing. Furthermore, these strains were confirmed serologically to be Salmonella Pullorum, Salmonella Enteritidis, and Salmonella Typhimurium (Table-2). On the other hand, strains were confirmed to be related to Salmonella spp. by invA specific PCR methods as all isolates showed positive bands at 284 bp (Figure-1).

Genotype identification was done using multiplex PCR assay with simultaneous characterization of Salmonella spp. generally. The results obtained showed that the three used strains were positive by PCR primers set (ST11, ST15) showing specific bands at 429 bp (Figure-2) for all Salmonella spp. Multiplex PCR could differentiate between Salmonella Enteritidis and Salmonella Typhimurium that showing sharp specific bands at 312 and $559 \mathrm{bp}$, respectively (Figure-2).

Duplex PCR for identification of Salmonella Pullorum results as shown in Figure-3 revealed a band at $220 \mathrm{bp}$ at $60^{\circ} \mathrm{C}$ annealing temperature only. None other bands were obtained by repeating the test with different PCR conditions. Furthermore, this test showed negative results or no product when tested with Salmonella Typhimurium and Salmonella Enteritidis. This band was purified for sequence analysis. The data obtained from sequence analysis of this fragment (data not shown) showed that this PCR fragment is not related to speC or glgC genes at all but it was related to yejBEF gene which is common among many other Salmonella spp.

\section{Discussion}

Salmonella contamination of eggs has been identified as a public health concern worldwide. Globally, Salmonella is one of the most prevalent causes of foodborne illness [19]. Culture techniques are universally recognized as standard methods for detection of bacterial pathogens, such as Salmonella in foodstuffs [20]. These techniques generally take longer time [8] and are less sensitive compared to PCR-based methods [21]. InvA gene specific PCR method is the most used in diagnostic and research laboratories, and Salmonella identification by molecular techniques is the simplest and less expensive method [10].
Table-2: Results of serotyping of Salmonella strains.

\begin{tabular}{lcccc}
\hline Salmonella groups and types & \multicolumn{3}{c}{ Antigenic formula } \\
\cline { 2 - 4 } & $\mathbf{0}$ & \multicolumn{2}{c}{$\mathbf{H}$} \\
\cline { 2 - 4 } & & $\mathbf{1}$ & $\mathbf{2}$ \\
\hline Salmonella Pullorum & $1,9,12$ & & \\
Salmonella Typhimurium & $1,4,5,12$ & $\mathrm{I}$ & 1,2 \\
Salmonella Enteritidis & $1,9,12$ & $\mathrm{~g}, \mathrm{~m}$ & $(1,7)$ \\
\hline
\end{tabular}

( ) = May be absent

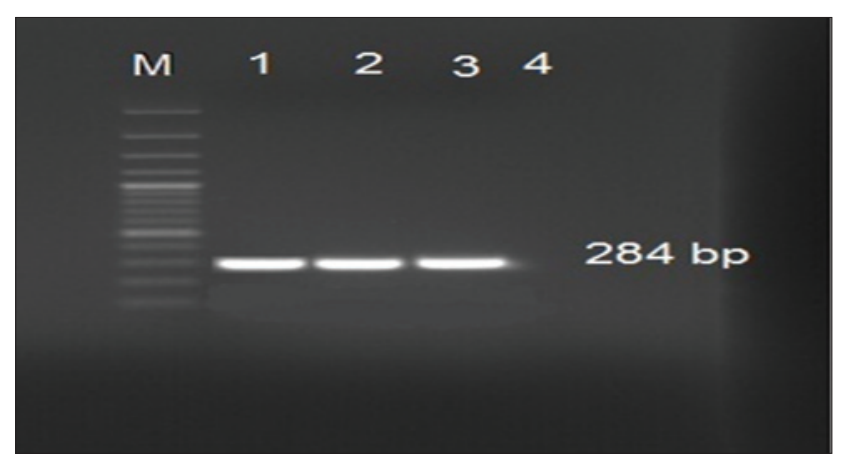

Figure-1: Agarose gel electrophoresis showing amplification of 284 bp of Inv A gene of Salmonella spp. Lane M: 100 bp DNA ladder (Fermentas), Lane 1: Salmonella Typhimurium, Lane 2: Salmonella Enteritidis, Lane 3: Salmonella Pullorum, Lane 4: Negative polymerase chain reaction control.

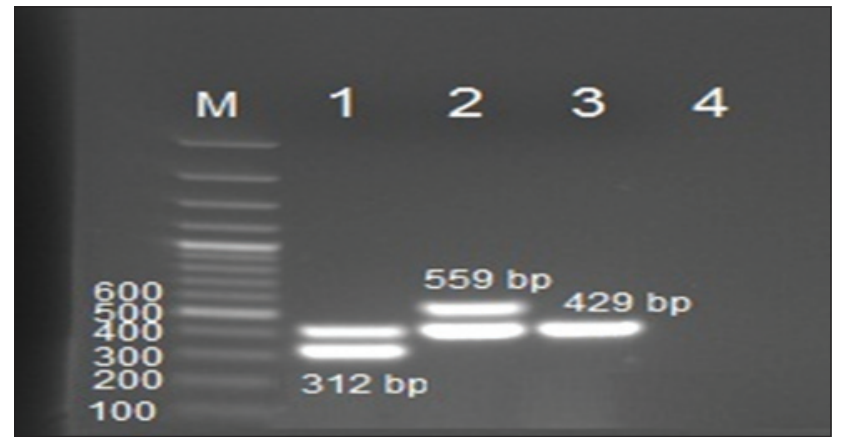

Figure-2: Genotyping of Salmonella strains by multiplex polymerase chain reaction (PCR). Lane M: 100 bp DNA ladder (Fermentas), All strains shared the same band at 429 bp which is general for all Salmonella spp. Lane 1 showed band at 312 bp specific for Salmonella Enteritidis. Lane 2 showed band at 559 bp specific for Salmonella Typhimurium, Lane 3 Salmonella Pullorum was negative for both Salmonella Typhimurium and Salmonella Enteritidis and showed only band 429 bp general for all Salmonella spp., Lane 4: Negative PCR control.

In this study, all the three locally field isolated strains used in the preparation of Salmonella antigens in Egypt were tested and confirmed phenotypically to be Salmonella Pullorum, Salmonella Enteritidis and Salmonella Typhimurium by culturing, biochemical testing and serological characterization. These strains were confirmed to be related to Salmonella spp. by invA specific PCR methods as all isolates showed positive bands at 284 bp (Figure-1) which agree with the previously reported results $[10,17]$. Genotype identification was done using multiplex PCR assay with simultaneous characterization of Salmonella spp. 


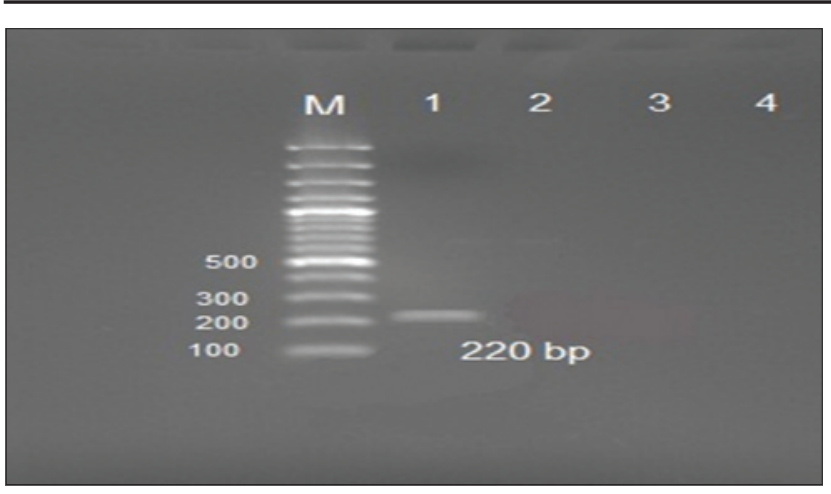

Figure-3: Duplex polymerase chain reaction (PCR) analysis to differentiate between biovars Gallinarum and Pullorum, Lane M: 100 bp DNA ladder (Fermentas), Lane 1: Salmonella Pullorum showing band at 220 bp, Lane 2: Salmonella Typhimurium, Lane 3: Salmonella Enteritidis, Lane 4: Negative PCR control.

generally. The results obtained showed that the three used strains were positive by PCR primers set (ST11, ST15) showing specific bands at 429 bp (Figure-2) for all Salmonella spp. Multiplex PCR could differentiate between Salmonella Enteritidis and Salmonella Typhimurium that showing sharp specific bands at 312 and $559 \mathrm{bp}$, respectively (Figure-2). Using the conventional PCR technique is a convenient tool for rapid and accurate identity of different Salmonella spp. as well as genotypic characterization of different Salmonella type either Salmonella Typhimurium, Salmonella Enteritidis and can be used as confirmatory tool with high sensitivity even if biochemical or serological tests were not available or the time factor is critical $[6,12]$.

Duplex PCR results as shown in Figure-3 revealed a band at $220 \mathrm{bp}$. It was not the expected specific size of Salmonella Pullorum at 174 bp [16] but it was the only band obtained at different PCR conditions as well as it was negative with other used strains. The possibility of insertions was reported previously through mapped genomes of serovar Pullorum [22] and its comparisons with the genomes of other Salmonella serovars revealed several insertions, deletions, and rearrangements in serovars Gallinarum [23]. All these results drove us to suspect that the resulted band at $220 \mathrm{bp}$ was due to nucleotide insertion either characteristic for Egyptian field isolates or due to serial passage. For clarification of this conflict, this band was purified for sequence analysis. The data obtained from sequence analysis of this fragment (data not shown) showed that this PCR fragment is not related to $\mathrm{speC}$ or $\mathrm{glgC}$ genes at all but it was related to yejBEF gene which is common among many other Salmonella spp. [24] that contributes to the virulence and antimicrobial resistance [25]. The false positive band at nonspecific size $220 \mathrm{bp}$ may be due to false priming of downstream primer of speC gene at yejBEF gene within Salmonella genome as the primer design was based on an $11 \mathrm{bp}$ deletion in the $g \lg C$ gene and a 4 bp deletion in speC. Furthermore, it was found that $\mathrm{glgC}$ gene was a pseudogene in
Salmonella Gallinarum while speC was a pseudogene in both biovars. In bacterial genomes, pseudogenes are continually created from ongoing mutational processes and are subject to degradation and removal by further accumulation of mutations. Their retention time seems to be extremely short and, even in very closely related bacteria, they tend to be deleted at a relatively rapid rate [26]. All these findings decreased the sensitivity and reliability of this duplex PCR. More investigations are required for rapid and easy identification of Salmonella Pullorum, as the previously reported conventional DNA-based methods are not feasible due to a high level of sequence similarities among Salmonella serovars as well as the limitation in resolution between biovars Gallinarum and Pullorum [27,28]. Furthermore, post-PCR steps as RFLP is laborious and time-consuming $[29,30]$.

\section{Conclusion}

The locally isolated field Salmonella strains were confirmed phenotypically and genotypically to be Salmonella Enteritidis and Salmonella Typhimurium and could be used for the preparation of Salmonella antigens. Further studies are required to develop and establish rapid and accurate protocols for genotyping of Salmonella Pullorum.

\section{Authors' Contributions}

HMI and HAA designed the work. HMI, DAMA and HAA conducted the research work. Data analysis and manuscript were written by HMI, DAMA and HAA under the guidance of MIE. All the authors have read and approved the final manuscript.

\section{Acknowledgments}

The authors are very much thankful to Veterinary Serum and Vaccine Research Institute for providing fund and all necessary facilities for conducting this research work.

\section{Competing Interests}

The authors declare that they have no competing interests.

\section{References}

1. Barrow, P.A., Jones, M.A., Smith, A.L. and Wigley, P. (2012) The long view: Salmonella - The last forty years. Avian Pathol., 41: 413-420.

2. Su, Y.C., Yu, C.Y., Lin, J.L., Lai, J.M., Chen, S.W., Tu, P.C. and Chu, C. (2011) Emergence of Salmonella Enterica serovar Potsdam as a major serovar in water fowl hatcheries and chicken eggs. Avian Dis., 55(2): 217-222.

3. Herikstad, H., Motarjemi, Y. and Tauxe, R.V. (2002) Salmonella surveillance: A global survey of public health serotyping. Epidemiol. Infect., 129: 1-8.

4. An, H., Zhang, D.H. and Chen, X.L. (2012) Isolation and identification of Salmonella Pullorum. Agric. Sci. Technol. J., 13: 661-663.

5. Gast, R.K., Mitchell, B.W. and Holt, P.S. (2004) Evaluation of culture media for detecting airborne Salmonella Enteritidis collected with an electrostatic sampling device from the environment of experimentally infected laying hens. Poultr. Sci., 83: 1106-1111. 
6. Grimont, P.A.D. and Weill, F.X. (2007) Antigenic formulae of the Salmonella serovars. In: W.H.O. Collaborating Centre for Reference and Research on Salmonella. $9^{\text {th }}$ ed. Institut Pasteur, Paris, France.

7. Zhu, Q., Lim, C.K. and Chan, Y.N. (1996) Detection of Salmonella typhi by polymerase chain reaction. Appl. Microbiol., 80: 244-251.

8. Malorny, B., Hoorfar, J., Bunge, C. and Helmuth, R. (2003) Multicenter validation of the analytical accuracy of Salmonella PCR: Towards an international standard. Appl. Environ. Microbiol., 69: 290-296.

9. Karmi, M. (2013) Detection of virulence gene (invA) in Salmonella isolated from meat and poultry products. Int. J. Genet., 3(2): 7-12.

10. Borges, K.A., Furian, T.Q., Borsoi, A., Moraes, H.L.S., Salle, C.T.P. and Nascimento, V.P. (2013) Detection of virulence associated genes in Salmonella Enteritidis isolates from chicken in South of Brazil. Pesq. Vet. Bras., 33(12): 14.

11. Liu, B., Zhou, X., Zhang, L., Liu, W., Dan, X., Shi, C. and Shi, X. (2012) Development of a novel multiplex PCR assay for the identification of Salmonella Enterica Typhimurium and Enteritidis. Food Control, 27: 87-93.

12. Soumet, C., Ermel, G., Rose, V., Drouin, P., Salvat, G. and Colin, P. (1999) Identification by a multiplex PCR based assay for Salmonella Enteritidis strains from environmental swabs from poultry houses. Lett. Appl. Microbiol., 29: 1-6.

13. Quinn, P.J., Markey, B.K., Leonard, F.C., Fitzpatrick, E.S., Fanning, S. and Hartigan, P.J. (2011) Veterinary Microbiology and Microbial Diseases. $2^{\text {nd }}$ ed. WileyBlackwell, Oxford, UK.

14. Kauffmann, F. and Das-Kaufmann, W. (2001) Antigenic formulas of the Salmonella serovars. $8^{\text {th }}$ ed. WHO Co-Operating Centre for Reference and Research on Salmonella, cited by Popoff, M.Y., Paris, France.

15. Rahn, K., De Grandis, S.A., Clarke, R.C., Curtiss, R. and Gyles, C.L. (1992) Amplification of an invA gene sequence of Salmonella Typhimurium by polymerase chain reaction as a specific method of detection of Salmonella. Mol. Cell. Probes, 6: 271-279.

16. Kang, M., Kwon, Y., Jung, B., Kim, A., Lee, K., An, B., Song, E., Kwon, J. and Chung, G. (2011) Differential identification of Salmonella Enterica subsp. Enterica serovars Gallinarum biovars Gallinarum and Pullorum based on polymorphic regions of $\mathrm{glgC}$ and $\mathrm{speC}$ genes. Vet., Microbiol., 147: 181-185.

17. Shanmgasamy, M., Velayutham, T. and Rajeswar, J. (2011) InvA gene specific PCR for detection of Salmonella from broilers. Vet. World, 4(12): 562-564.

18. Mamman, P.H., Kazeem, H.M., Raji, M.A., Nok, A.J. and Kwaga, J.K.P. (2014) Isolation and characterization of Salmonella Gallinarum from outbreaks of fowl typhoid in Kaduna State, Nigeria. Int. J. Public Health Epidmiol., 3(10): 82-88.
19. Whiley, H. and Ross, K. (2015) Salmonella and eggs: From production to plate. Int. J. Environ. Res. Public Health, 12: 2543-2556.

20. White, P., Meglli, K., Collins, D. and Gormely, E. (2002) The prevalence and PCR detection of Salmonella contamination in raw poultry. Vet. Microbiol., 89: 53-60.

21. Oliveira, S.D., Santos, L.R.D., Schuch, M.T., Silva, A.B.C., Salle, T.P. and Canal, C.W. (2002) Detection and identification of Salmonellas from poultry-related samplesby PCR. Vet. Microbiol., 87: 25-35.

22. Liu, G.R., Rahn, A., Liu, W.Q., Sanderson, K.E., Johnston, R.N. and Liu, S.L. (2002) The evolving genome of Salmonella enteric serovars Pullorum. J. Bacteriol., 184: 2626-2633.

23. Wu, K.Y., Liu, G.R., Liu, W.Q., Wang, A.Q., Zhan, S., Sanderson, K.E., Johnston, R.N. and Liu, S.L. (2005) The genome of Salmonella Enterica serovars Gallinaram: Distinct insertions/deletions and rare rearrangements. J. Bacteriol., 187(14): 4720-4727.

24. Dhanani, A.S., Block, G., Dewar, K., Forgetta, V., Topp, E., Beiko, R.G. and Diarra, M.S. (2015) Genomic comparison of non-Typhoidal Salmonella Enterica serovars Typhimurium, Enteritidis, Heidelberg, Hadar and Kentucky isolates from broiler chickens. PLoS One, 10(6): e0128773.

25. Eswarappa, S.M., Panguluri, K.K., Hensel, M. and Chakravortty, D. (2008) The yejABEF operon of Salmonella confers resistance to antimicrobial peptides and contributes to its virulence. Microbiology, 154: 666-678.

26. Batista, D.F.A., Freitas Neto, O.C., Lopes, P.D., Almeida, A.M., Barrow, P.A. and Berchieri, A.Jr. (2013) Polymerase chain reaction assay based on ratA gene allows differentiation between Salmonella Enterica subsp. Enterica serovars Gallinarum biovars Gallinarum and Pullorum. J. Vet. Diagn. Invest., 25: 259-262.

27. Feng, Y., Johnstone, R.N., Liu, G.R. and Liu, S.L. (2013) Genomic comparison between Salmonella Gallinarum and Pullorum: Differential pseudogene formation under common host restriction. PLoS One, 8(3): e59427.

28. Batista, D.F.A., Freitas Neto, O.C., Barrow, P.A., Oliveira, M.T., Almeida, A.M., Ferraudo, A.S. and Berchieri, A.Jr. (2015) Identification and characterization of regions of difference between the Salmonella Gallinarum biovar Gallinarum and Salmonella Gallinarum biovar Pullorum genomes. Infect. Genet. Evol., 30: 74-81.

29. Taddele, M.H., Rathore, R., Dhama, K. and Agarwal, R.K. (2011) Epidemiological characterization of Salmonella Gallinarum isolates of poultry origins in India, employing two PCR based typing methods of RAPD-PCR and PCRRFLP. Asian J. Anim. Vet. Adv., 6(11): 1037-1051.

30. Cheraghchi, N., Khaki, P., Bidhendi, S.M. and Sabokbar, A. (2014) Identification of Salmonella Enterica serotype Gallinarum biotype Pullorum and Gallinarum by PCRRFLP. Jundishapur J. Microbiol., 7(9): e19135.

\section{$* * * * * * * *$}

